\title{
The Ultimate Rotating Resistance of the Belt Conveyors Rollers
}

\author{
Alexander Zakharov \\ Mining Department \\ T.F. Gorbachev Kuzbass State \\ Technical University \\ Kemerovo, Russian Federation \\ auzaharov@rambler.ru
}

\author{
Boris Gerike \\ Mining Department \\ T.F. Gorbachev Kuzbass State \\ Technical University \\ Kemerovo, Russian Federation \\ gbl_42@mail.ru
}

\author{
Dmitriy Shiryamov \\ Mining Department \\ T.F. Gorbachev Kuzbass State \\ Technical University \\ Kemerovo, Russian Federation \\ shiryamov@list.ru
}

\begin{abstract}
Belt conveyors are widely used in various transport systems. The major cost for their operation consists, most often, of the means for rollers maintenance especially when belt conveyors are in the dusty explosive environment, for example, in mining industry. To prevent or reduce probability of fires, it is necessary to prevent jamming of rollers. For this purpose the ultimate resistance of conveyor rollers at which their rotation stops, depending on the degree of filling of the belt cross-section area with cargo, locations of an idler in a support and condition of the contact surfaces of a roller with a belt has been defined. The adhesion coefficient of a roller with the conveyer belt has been defined experimentally on the full-size conveyor $1 \mathrm{LBO}$ at the laboratory of Kuzbass State Technical University applying specially manufactured device, furthermore the status of the contact surfaces of a belt and rollers has been altering by wetting. The analytical researches have been conducted on the basis of the theory of elasticity and laws of mechanics.
\end{abstract}

Keywords -belt conveyor, rollers, rotation resistance, adhesion coefficient

\section{INTRODUCTION}

Operation of belt conveyers at minining eterprises is characterized by severe conditions due to impact of uneven dynamic loads, considerable dust content of the air, and quite often high humidity and aggression of the environment [1] These factors make considerable negative impact on durability of the idlers, to be exact - their bearing units. Therefore servicing cost of a roller flight remain an essential part of the operating cost

By the results of testing of rollers in dust cameras [2] and estimation of their working capacity under industrial conditions it was determined that process of their degradation is followed by the gradual growth of resistance to rotation $[3,4]$. It is connected with the fretting wear of rolling bearings, and also with gradual pollution of plastic lubricant in them. As a result, the general resistance to movement of a belt increases, the probability of its gap gets greater, energy consumption of traction engines and load on driving blocks of the conveyor increases.

When a roller achieves its ultimate rotating resistance it stops, shell starts to grind off quickly by moving belt that leads to formation of sharp edges what later can become a reason of belt serious damages. There are well known cases when defective rollers became the cause of fire [5]. Therefore, in order to increase reliability of operation of the belt conveyor it is required to upgrade rollers, as well as to run periodic diagnostics of them to detect and eliminate all defected and failed idlers[6].

The most perspective method of preventive maintenance for a roller flight is maintenance according to the actual technical condition based on experimental data obtained based on functional diagnostics [7,8]. As a criterion of roller defect it is offered to take some resistance reference value of rotation determined based on condition of achievement of the smallest operating expenses. It is required to estimate current resistance of rollers in regard to the ultimate rotating resistance, and the decision on their replacement should be made based on the condition of excess of the actual resistance over reference value. Such approach, in the first place allows preventing beforehand jamming of rollers, secondly to manage energy consumption of engines, and to thirdly to increase reliability of basic elements of the conveyor.

Figure 1 presents the phenomenon of unstable rotation of the rollers which were operated on development belt conveyor, where relatively low loadings are customary. The bearings of the roller \#1 are not destroyed and its axis is given to rotation with some effort. Throughout wear of the middle part of the shell allows to understand that on the conveyor the roller was in the steady jammed state, however increase in load on the roller could lead to renewal of its movement about what not damaged bearings testify to. On the roller \#2 there are two distinct sides of wear which were formed due to the unstable rotation and numerous stops.

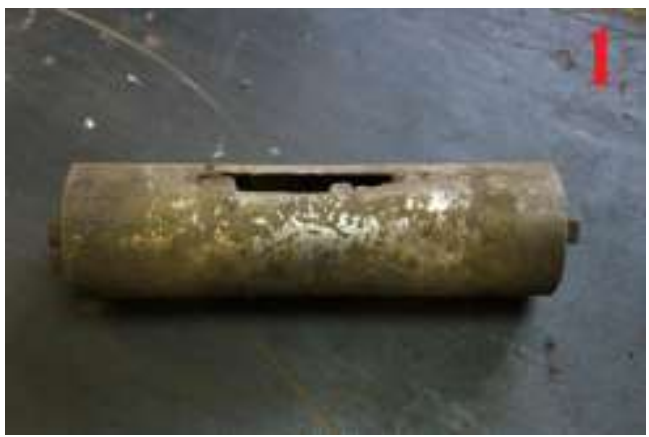




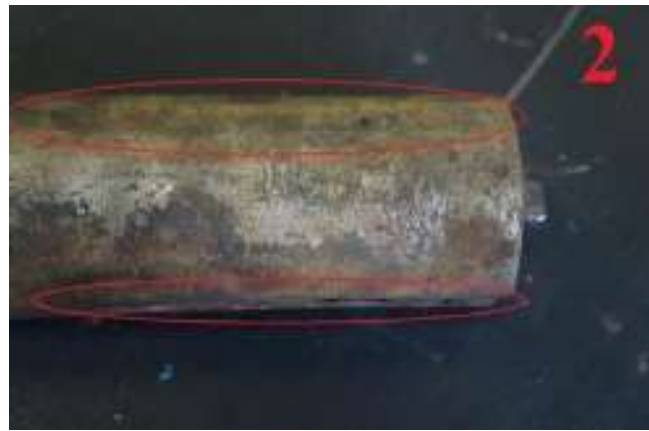

Fig. 1. Rollers wear characteristic at jamming

Therefore at maintenance of roller flight it is necessary to make adjustment of the reference rotating resistance taking into account the ultimate resistance when roller passes into the mode of unstable rotation. Especially it should be considered for the conveyors working at low belt loading and also for those rollers which are exposed to low external loadings. Rollers of empty conveyor and side rollers of operating conveyor are the subject of the above said [9].

\section{THEORETICAL BASICS}

It is known, during operating time of a conveyor the belt being the traction and cargo bearing body, moves along a roller flight and, interacting with idlers, bringing them into rotation. The driving force $F_{m}$, transferred to one roller is equal to the sum of the forces of resistance to the movement of this roller (Fig. 2) $F_{m}=U_{w d}+U_{w r}$ where $U_{w d}$ is the resistance caused by cave-in of a roller into belt, $\mathrm{H}$; $U_{w \mathrm{r}}$ is the resistance in bearing units of a roller.

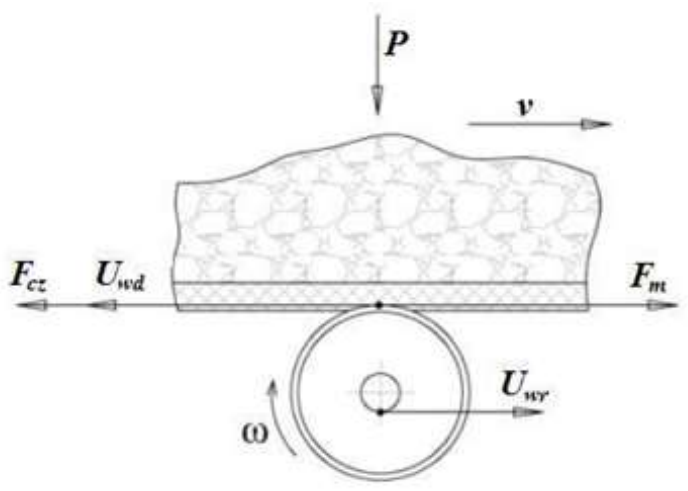

Fig. 2. Interaction of the moving belt of conveyor with idler

Thereat maximum value $F_{m}$ is limited by force of adhesion $F_{c z}$ of belt with a roller, i.e. $F_{m} \leq P \psi$, where $P$ is the load on a roller from belt weight and transported cargo, $\mathrm{H} ; \psi$ is the adhesion coefficient of a belt with a roller. During operation the resistance of a roller increases, and when it reaches some critical value $U_{w r k}$, the sum of resistances to movement of a roller begins to exceed hauling capacity on adhesion that leads to the termination of its rotation and a roller failure $U_{w d}+U_{w d k} \geq P \psi$ hence

$$
U_{w d k}=P \cdot \psi-U_{w d}
$$

The load on rollers of a cargo flight of conveyor can be presented as

$$
P=\zeta \cdot\left(G_{l}+G_{g r}\right)
$$

where $\zeta$ is the weight share on a roller out of total load; $G_{l}$, , $G_{g r}$ is the belt weight and cargo fright on one idle, $\mathrm{H}$ :

$$
G_{l}=M_{l} \cdot B \cdot l_{p q} \cdot g
$$

where $M_{l}$ is the mass of square meter of conveyor belt, $\mathrm{kg} / \mathrm{m}^{2}$; $B$ is the width of a belt, $\mathrm{m} ; l_{p q}$ is the idler spacing of the operating belt flight, $\mathrm{m} ; g$ - acceleration of free fall, $\mathrm{m} / \mathrm{sec}^{2}$;

$$
G_{g r}=\int_{t_{1}}^{t_{2}} Q(t) d t
$$

where $Q(t)$ is the weight of cargo on a section of the moving conveyor belt; $t_{2}-t_{1}$ the time of the belt movement between two idlers. Let's accept an assumption that the quantity of cargo (cross-section area of cargo) which is on a belt is invariable in time, then

$$
G_{g r}=\varepsilon \cdot F \cdot l_{p q} \cdot \gamma \cdot g
$$

where $F$ is the cross-section area of cargo on a belt, $\mathrm{m}^{2}$; $\varepsilon$ is the coefficient of filling of cross-sectional area of a belt with freight ( $\varepsilon=1$ at $100 \%$ loading); $\gamma$ is the bulk density of the loosened transported cargo, $\mathrm{kg} / \mathrm{m}^{3}$.

It is known that a middle roller of an operating conveyor flight is the most loaded. Thereat the engineering calculations show that the value $\zeta$ for the middle roller is accepted as of 0.7 [9]. However, as a result of pilot studies $[10,11]$, it was recognized that the value of loading share of the upper flight of the conveyor changes in time and depends on degree of filling of cross-section of a belt conveyer. Thus, under full load of conveyor $(\varepsilon=1)$ the middle roller takes about $45 \%$ of the total load on itself. Thereat, with reduction of the belt conveyer load to $\varepsilon=0.5$, the load on the middle roller increases up to $60 \%$, and in case of further decrease in quantity of cargo on a belt $(\varepsilon=0.1)$ the load between rollers is distributed almost evenly (the middle roller takes $30 \%$ out of the total load).

Let's make one more assumption that at the full load of the conveyor the cross-section area of cargo on the belt $F$, when a three-roller support is applied, consists of a trapeze and triangle, then:

$$
F=\frac{b^{2}}{4}\left\{[\cos \beta+\Theta(1-\cos \beta)]^{2}(\operatorname{tg} \varphi+\operatorname{tg} \beta)-\Theta^{2} \operatorname{tg} \beta\right\}
$$

where $b$ is the operating width of the conveyer belt, $b=0,8 B$; $\beta$ is the tilt angle of side rollers, degree; $\Theta=l_{p} / b ; l_{p}$ is the length of a roller, $\mathrm{m} ; \varphi$ - angle of the natural levee of the transported material, degree.

Substituting values in the expressions (3), (4), (5) in equation (2), finally there will be: 


$$
P=\zeta M_{l} B l_{p q}+\varepsilon\left[\frac{(0,8 B)^{2}}{4} K l_{p q} \gamma g\right]
$$

where $K=\left\{[\cos \beta+\Theta(1-\cos \beta)]^{2}(\operatorname{tg} \varphi+\operatorname{tg} \beta)-\Theta^{2} \operatorname{tg} \beta\right\}$.

Then the load applied on the roller of a two-roller support of empty flight of conveyor, if there is no cross movement of the belt, it is possible to present as $P_{p o r}=0.5 M_{l} B l_{p p} g$, where $l_{p p}$ is the roller spacing of empty belt conveyer flight.

To determine resistance on idler due to cave-in the following expression should be expedient [12]:

$$
U_{w d}=\xi \sqrt{\frac{8\left[\left(q_{l}+q_{g}\right) g l_{p q}\right]^{3}\left(1-\mu^{2}\right)}{\pi R B E}},
$$

where $\xi$ is the coefficient, for the uploaded belt $\xi=0.17$, for the empty belt $\xi=0.32 ; q_{l}, q_{g}$ is the linear weight to the cargo and belt accordingly, $\mathrm{kg} / \mathrm{m}: q_{l}=B M_{l}, q_{g}=Q_{n} / v$, where $v$ is the belt velocity, $\mathrm{m} / \mathrm{sec} ; \mu$ is the Poisson ratio, for materials made of resin $\mu \approx 0.475 ; R$ is the radius of the roller, $\mathrm{mm} ; E$ is the module of elasticity of the lower facing, $E \approx 5-5.5 \mathrm{MPa}$; $Q_{n}$ - estimated nominal productivity of the belt conveyor, $\mathrm{kg} / \mathrm{sec}, Q_{\mathrm{n}}=V \gamma$, where $V$ is the load capacity of the conveyer, $\mathrm{m}^{3} / \mathrm{sec}: V=\varepsilon F v$.

Linear loading form the cargo weight, considering expressions $Q_{\mathrm{n}}$ and $V$, is possible to write down as follows: $q_{g}=\varepsilon K \gamma(0.8 B)^{2} / 4$.

Then the dependence for determination of resistance from cave-in of a roller into a belt will be as

$$
U_{w d}=\xi \sqrt{\frac{8\left[\left(\varepsilon \frac{(0.8 B)^{2}}{4} K \gamma+M_{l} B\right) g l_{p q}\right]^{3}\left(1-\mu^{2}\right)}{\pi R B E}}
$$

Thereat we assume that resistance $U_{w d}$ remains invariable throughout the service life of a roller and depends only on design data of the conveyor and load rate. As the expression (8) is suggested to define resistance on one idler, with the aforesaid assumption, to figure out resistance $U_{w d}$ on one roller it is necessary to enter the coefficient $\zeta$ into the formula considering the load rate on the roller from total linear weight of the belt and cargo.

Substituting values of the expressions (6) and (8) in the equation (1) and considering the aforesaid, the final formula for determination of the critical resistance to rotation will have as follows:

$$
U_{w r k}=\zeta\left(M_{l} B l_{p q} g+\varepsilon \frac{(0.8 B)^{2}}{4} K l_{p q} \gamma g\right) \psi-
$$

$$
-\xi \sqrt{\frac{8\left[\left(\varepsilon \frac{(0.8 B)^{2}}{4} K \gamma+M_{l} B\right) g l_{p q}\right]^{3}\left(1-\mu^{2}\right)}{\pi R B E}}
$$

To determine resistance to rotation of a roller in compliance with the expression, it is necessary to have adhesion coefficient $\psi$ of a roller surface with a moving belt. It was experimentally figured out on the full-size belt conveyer 1L80 at the laboratory of Kuzbass State Technical University. For this purpose $900-\mathrm{mm}$ roller was installed on a working flight of the conveyor to the edge of which a shoe brake (Fig. 3) was pressed by set of levers to the specially prepared surface that allowed changing resistance to rotation of the roller. By means of a load trolley the roller under experiment was exposed to the true load from the transported cargo $P$ [13]. The initial stop moment of rotation of the roller was defined after a start of the conveyor by regulating of the force on the brake mechanism.

a)

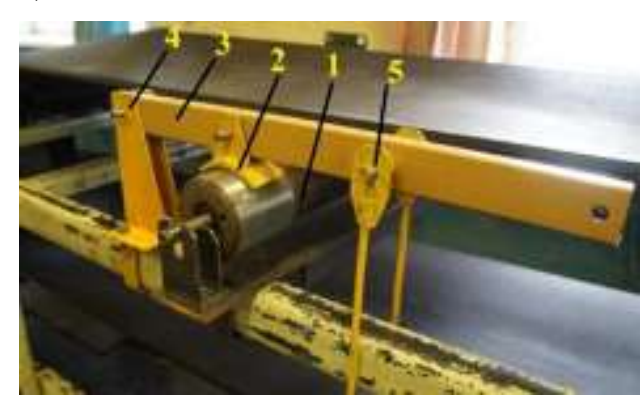

b)

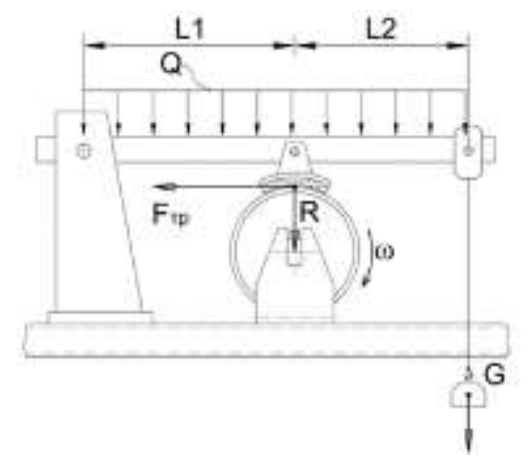

Fig. 3. Brake Mechanism for Modeling of Resistance Change to Rotation of a Roller: a) general view: 1 - conveyor roller; 2 - shoe brake; 3 - lever; 4 - support; 5 - an eye-bar for replaceable cargo; b) flowsheet of forces

In this case we have the equation $F_{c z}=U_{w d}+U_{w r}+F_{m p . c k}$ or $P \psi=U_{w d}+U_{w r}+R \mathrm{f}$, where $F_{m p . c k}$ is the between-shoe-androller sliding friction force, $\mathrm{H} ; R$ is the pressing force of shoe to roller, $\mathrm{H} ; \mathrm{f}$ is the between-shoe-and-roller friction coefficient, the value of which for the given friction contact was defined by experiment $(\mathrm{f}=0.42)$.

Thus, expressing the friction coefficient $\psi$ we will get:

$$
\psi=\frac{R f}{P}+\frac{U_{w r}+U_{w d}}{P}
$$

where $P$ - the load on roller created by belt mass, trolley and cargo on it. 
The force value $R$ was calculated from the following formula in accordance with the flowsheet of forces (Fig. $3 \mathrm{~b}$ ):

$$
R L_{1}=G\left(L_{1}+L_{2}\right)+Q \frac{L_{1}}{2}+Q\left(L_{1}+\frac{L_{2}}{2}\right)
$$

Taking into account the said hereinabove, the expression (10) will be as follows:

$$
\psi=\frac{G\left(L_{1}+L_{2}\right)+Q \frac{L_{1}}{2}+Q\left(L_{1}+\frac{L_{2}}{2}\right) f+U_{w r}+U_{w d}}{L_{1} P}
$$

\section{RESULTS AND DISCUSSIONS}

The experiment has been repeated ten times applying various value of the load on the idler $P$, then an average value $\psi$ was calculated based on a series of repetitions. The expression for the resistance force to rotation $U_{w r}$ could be presented as follows:

$$
U_{w \gamma}=(a+b \cdot v) \cdot \alpha_{\theta}+C_{o} \cdot F_{o}+C_{p} \cdot P
$$

where $a$ and $\mathrm{b}$ are the constructive constants (for 204 bearing $a=0.85 \mathrm{H}, b=0.5 \mathrm{H} \cdot \mathrm{sec} / \mathrm{m}$, for $304 a=1.3 \mathrm{H}, b=0,2$ $\mathrm{H} \cdot \mathrm{sec} / \mathrm{m}[14] ; \alpha_{\theta}$ is the average temperature coefficient, at the operational temperature of the conveyer $+10^{\circ} \mathrm{C} \alpha_{\theta}=1.1$ [9] and greater; $C_{o}$ is the coefficient of the axial load $\left(15^{\cdot} 10^{-6}\right)$; $F_{o}$ is the axial load; $C_{p}$ is the coefficient of radial load $\left(16 \cdot 10^{-5}\right) ; P$ is the radial load applied on the roller.

The experiments have shown that at dry contact the 89$\mathrm{mm}$ roller and the belt moving at speed of $0.5 \mathrm{~m} / \mathrm{sec}$, the adhesion coefficient $\psi$ is equal to 0.45 , and at damp contact 0.28 .

The table below demonstrates the results of the comparative evaluation of the initial $U_{w r}$ and ultimate resistance of rollers for the conveyor with the width of the belt of $800 \mathrm{~mm}$ at dry interaction contact.

TABLE I. RELATION OF THE ULTIMATE RESISTANCE TO IDLER ROTATION TO THE INITIAL RESISTANCE

\begin{tabular}{|c|l|l|l|l|l|l|}
\hline \multirow{2}{*}{ Type of roller } & \multicolumn{5}{|c|}{ B=800MM } & \multicolumn{2}{c|}{$\boldsymbol{\varepsilon = 0 . 1}$} \\
\cline { 2 - 7 } & \multicolumn{2}{|c|}{$\boldsymbol{\varepsilon}=\mathbf{1}$} & \multicolumn{2}{c|}{$\boldsymbol{\varepsilon}=\mathbf{0 , 5}$} & Average & Side \\
\cline { 2 - 6 } & Average & Side & Average & Side & Ava \\
\hline$U_{w r k}-U_{w d}$ & 85 & 52 & 68 & 23 & 16 & 18 \\
\hline
\end{tabular}

\section{CONCLUSION}

The obtained results showed that the resistance to rotation of conveyor idlers during operating time can increase in ten times, and their untimely replacement can lead to essential increase in power consumption for transportation and decrease in reliability of units of a conveyor. Running maintenance of belt conveyor flight based on data of the actual technical condition, and so applying methods of nondestructive control, and knowing the value of critical rotating resistance, it is possible to predict rational time for replacement of defective rollers.

\section{REFERENCES}

[1] Lutynski A., Industrial research of modern belt conveyors for underground mining[M]. Silesian University of Technology. Gliwice, 2005.

[2] D'jachkov V.K. Issledovanie rolikoopor lentochnyh konvejerov[J]. Rudnichnyj transport. - 1958, 12: 89-101.

[3] Antonjak E. Sravnenie metodov izmerenija, ispol'zuemyh dlja ocenki tehnicheskogo sostojanija rolikov[J]. Gornyj informacionnoanaliticheskij bjulleten', 2006, 1: 305-309.

[4] Kravchenko V.M. Tehnicheskoe obsluzhivanie i diagnostika promyshlennogo oborudovanija[M]. - Doneck: OOO «Jugo-Vostok, Ltd», 2006.

[5] Baskakov V.I., Gerasimov G.K., Ludzish V.S. Pozhary na konvejernom transporte[J]. Bezopasnost' truda $\mathrm{v}$ Promyshlennosti, 2000, 1: 41- 43

[6] Stefaniak P., Zimroz R., Król R., Górniak-Zimroz J., Bartelmus W., Hardygóra M.. Some Remarks on Using Condition Monitoring for Spatially Distributed Mechanical System Belt Conveyor Network in Underground Mine - A Case Study. Condition Monitoring of Machinery in Non-Stationary Operations. Springer, 2012, 497-507.

[7] Zakharov A.Ju., Shirjamov D.A. Dinamicheskoe izmerenie temperatury rolikov len-tochnogo konvejera na osnove priemnika IRA-E420S1 [Jelektronnyj re-surs] Sb. materialov VI Vseros., 59-j nauch.-prakticheskoj konf. $\mathrm{s}$ mezhdunar. uchastiem «Rossija molodaja». - Kemerovo, 2014, http://science.kuzstu.ru/wpcontent/Events/Conference/RM/2014/materials/

[8] Zakharov A.Ju., Shirjamov D.A. Datchik dlja beskontaktnogo izmerenija temperatury rolikov lentochnogo konvejera vo vremja ego raboty, Sb. materialov III Mezhdunar. nauch.-praktich. konf. «Sovremennye tendencii i innovacii v nauke i proizvodstve», Kemerovo, 2014, 34-35.

[9] Shahmejster L.G., Dmitriev V.G. Teorija i raschet lentochnyh konvejerov[M]. Moscow, Mashinostroenie, 1978.

[10] Peruń G., Opasiak T. Evaluation of technical state of the belt conveyor rollers using vibroacoustics methods - preliminary studies[J]. Diagnostyka, 2016, 17(1); 75-81.

[11] Bajda M., Krol R. Experimental Tests of Selected Constituents of Movement Resistance of the Belt Conveyors Used in the Underground Mining[J]. Procedia Earth and Planetary Science, 2015, $15 ; 702-711$.

[12] Galkin V.I., Dmitriev, V.P. [i dr.] Sovremennaja teorija lentochnyh konvejerov gornyh predprijatij[M]. Moscow, MGGU, 2005.

[13] Zakharov A.Ju., Shirjamov D.A. Razrabotka stenda dlja imitacii nagruzki ot gruza na rolik lentochnogo konvejera [Jelektronnyj resurs], Sb. materialov XV mezhdunar. nauch. praktich. konf. «Prirodnye i intellektual'nye resursy Sibiri. Sibresurs 2014». Kemerovo, 2014, URL: http://science.kuzstu.ru/wpcontent/Events/Conference/Sibresource/2014/materials/

[14] Dmitriev V.G., Sergeeva N.V. Metodika tjagovogo rascheta lentochnogo trubchatogo konvejera[J]. GIAB, 2011, 7; 218-228. 